\title{
SAVINGS AND LOAN CRISIS AND MARKET REGULATIONS
}

\author{
A. Konar \\ Institute of Management Accountants, Doha, Qatar
}

This article provides an analysis on the key role players from the inception to the demise of the Savings and Loan market, shortfalls of the regulation which affected the Savings and Loan market and the level of regulation of the Garn-St. Germain Depository Institutions Act.

Keywords: Savings and Loan crisis, market regulations, deregulation, thrifts.

\section{Introduction}

At our time, such words as crisis and recession have become a part of our day-to-day vocabulary. According to the research conducted by Deutsche Bank in 2017, the frequency of financial crises has increased. It makes us wonder whether we are able learn from our mistakes and slow down the rate of the economic downfalls. The interest of the academia is riveted on the Great Depression of 1929-1939 and the global financial crisis of 2008-2009; however, the economic catastrophes between these two events are not studied as thoroughly, and the 1980s' Savings and Loan Crisis falls into that category.

It can be inferred from its name that the Savings and Loan debacle involved the crash of the Savings and Loan market. One hundred years ago, the U.S. banking system was reluctant to finance common citizens with home mortgages. Under the force of high demand for affordable home ownership, the savings and loan associations, called thrifts, were established in the 1930s (Metaxas \& Trompatzi, 2015). The thrifts were allowed to receive deposits and grant loans, mostly home mortgages, to the local residents. The deposits were insured by the U.S. government, and in return, the thrifts were obliged to invest at least $65 \%$ of their assets into the residential mortgages. Moreover, the mortgage interest was capped in order to make home ownership affordable to common people (Jang, 2015). Such an advantageous symbiosis became extremely popular making thrifts a significant part of the U.S. financial industry. That is why the crisis had serious consequences on the whole financial system - it cost $\$ 160$ billion to the U.S. economy (Pusey, 2017).

T. Metaxas and G. Trompatzi (2015) regard "the structural problems of the industry, the imprudent actions of the policy decision makers and the imperfect and restrictive regulatory environment of the financial sector in general" to be the main causes of the Savings and Loan crisis. B. Jang (2015) lists more distinct causes:

1. Economic circumstances. The U.S. government increased interest rates in order to beat the inflation of the 1970s. Investors realised it was more profitable to keep their money in banks or in money market mutual funds (MMMFs), so the thrifts had to increase their deposit interest rate in turn. As the mortgage interest rates were capped, the thrifts experienced an imbalance between the interest receivable and the interest payable.

2. Deregulation. In the $1980 \mathrm{~s}$, in attempt to solve thrifts' problems, the U.S government decided to ease the regulations. In particular, the capital requirement was decreased from five to four and then to three percent, the accounting rules were changed in favour of showing no longer existing assets on the balance sheets, the investment in riskier assets was allowed; the requirements for a number of total shareholders, the share of local resident shareholders, and the cap for percentage of share per shareholder were abolished.

3. Increased deposit insurance. As the deposits were insured by the U.S. government up to $\$ 100,000$ in the 1980s instead of the earlier $\$ 40,000$, the thrifts engaged themselves in high-risk and high-return investments.

4. Moral hazard. The deregulation allowed the thrifts to engage in riskier or even illegal activities, and increased deposit insurance kept them safe from supervisory bodies. A. Pusey provides an illustrative example of Empire, "the first-ever savings institution closed due to fraud" (2017).

5. Delayed policy and mergers. Instead of closing the insolvent thrifts, the U.S. Government decided to merge them with prime institutions, which worsened the situation (Jang, 2015).

Although the importance of all the above causes is indisputable, T. Metaxas and G. Trompatzi (2015) found an intense disagreement in the academic literature over whether too loose or too restrictive regulations were the main cause of the crisis. We attempt to have a closer look at the U.S. regulations, related to that subject. The purpose of this article is to produce a review of scientific research, conducted on the Savings and Loan crisis within the last 8 years, and from the distance of almost three decades to:

1. Identify key role players from the inception to the demise of the Savings and Loan market.

2. Analyse shortfalls of the regulation which affected the Savings and Loan market.

3. Make an argument for which level of regulation the Garn-St. Germain Depository Institutions Act was.

The remainder of this paper is organised as follows. Section 2 presents the methodology. Section 3 
identifies key role players from the inception to the demise of the Savings and Loan market. Section 4 analyses shortfalls of the regulation which affected the Savings and Loan market. Section 5 makes an argument for which level of regulation the Garn-St. Germain Depository Institutions Act was. The last section summarizes the findings and states the conclusion.

\section{Methodology}

The analysis is exploratory in nature and is based on an extensive review of earlier relevant studies on the various aspects of the Savings and Loan crisis and its interrelation with markets regulations. The basis of the analysis is a collection of articles, published in credible scientific journals within the last 8 years.

Key role players from the inception to the demise of the Savings and Loan market

The Savings and Loan market was regulated by a number of organisations. In the U.S.A., the Federal Reserve System (FRS), responsible for regulatory and monetary policies, supervises the Federal Reserve Banks (FRB), which perform the last resort function to all the other financial institutions in the U.S.A. Under the Federal Mortgage Banking Act of 1932, the Federal Home Loan Bank Board (FHLBB) was established to insure the functioning of the savings and loan mechanisms with a reserve system. In 1934, the Federal Savings and Loan Insurance Corporation (FSLIC) was established for the thrift industry under the $\mathrm{Na}$ tional Housing Act. The FSLIC encouraged the issuance of long-term, fixed-rate mortgages (LTFRM). The Interest Rate Control Act (IRCA) of 1966 authorised the FHLBB to establish interest-rate ceilings for the thrifts that were 25 basis points higher than those for commercial banks under the condition that the thrifts invested a large part of their assets in mortgages (Steinreich \& Oglesby, 2016).

T. Metaxas and G. Trompatzi (2015) distinguish three main players, responsible for the inception of the crisis:

1) the U.S. Federal Reserve Banks, which allowed double-digit inflation, and hence, higher nominal interest rates;

2) the U.S. Congress and Council, who ignored the increase of interest rates;

3 ) the FHLBB, which ignored high risk operations in the industry.

The researchers note that the regulatory authorities were disjoined in their functions, could not cooperate, and thus, no one had sole responsibility for the crisis (Metaxas \& Trompatzi, 2015). B. Jang (2015) specifies that it was the Reagan administration that "eased the regulatory environment on the thrift industry by lessening the size of regulatory agencies and by reducing intervention on the industry".

As the crisis became obvious, the U.S. Government took steps to overcome it with the creation of new acts. Under the Financial Institutions Reform, Recovery, and Enforcement Act of 1989 (FIRREA) and the Federal Deposit Insurance Corporation Improvement Act of 1991 (FDICIA), the regulatory system of the Savings and Loan market was reorganised. The FHLBB was substituted with the Office of Thrift Supervision (OTS), and the FSLIC was abolished in favour of the Federal Deposit Insurance Corporation (FDIC), who became responsible for the newly created Resolution Trust Corporation (RTC) and the Savings Association Insurance Fund (SAIF) (Jang, 2015).

As we can see, many organizations played a significant role in the inception to the demise of the Savings and Loan market. However, the main decision makers, who defined the direction of development of the market and the strategy of beating the crisis, in our opinion, had always been the U.S. Presidents and the U.S. Congress, who alone had the power to abolish old regulators, create new ones and issue restrictive or liberal legislation, regulating the market. Moreover, they alone had a bigger picture of the state economy, which all the established regulatory authorities, described above, had the information and the influence within their limited scope (that is within the Savings and Loan market only).

Shortfalls of the regulation that affected the Savings and Loan market

We distinguish three phases of the Savings and Loan market regulation: Restrictive I, Liberal and Restrictive II, presented on Figure 1.

The first phase is known for the boom of the Savings and Loan industry. Federal Mortgage Banking Act of 1932, National Housing Act of 1934 and Interest Rate Control Act of 1966 restricted the activities of the thrifts and insured them to the point that the industry became perceived as risk-free. Such a regulation was beneficial in the static conditions of the postGreat Depression period. However, with the development of financial markets, the overregulated thrifts lost their competitiveness to the Money Market Mutual Funds (MMMFs), established in the 1970s. Thus, in the first phase of 1930s-1970s the Savings and Loan Market suffered from the overregulation, and as a result by 1980, 330 thrifts had problems and 11 failed (Steinreich \& Oglesby, 2016).

The second phase is characterised by the attempt of the U.S. Government to fix the Savings and Loan Market's growing problems by deregulation. In the 1980s, at the peak of the confrontation of Capitalism and Socialism, the U.S. politicians were reluctant of imposing further regulations on the Savings and Loan industry in fear that their actions could be viewed as pro-socialist. At the same time, their strong belief in Adams' invisible hand of free market lead them to the idea of market deregulation. During the first phase the risk-averse restrictions of the thrifts' activities were balanced with the insurance, adequate to the risk. However, as the second phase deregulation has lifted the restrictions, increasing the risk, the insurance of deposits was also increased. This move of regulatory authorities does not seem logical: the thrifts were pri- 


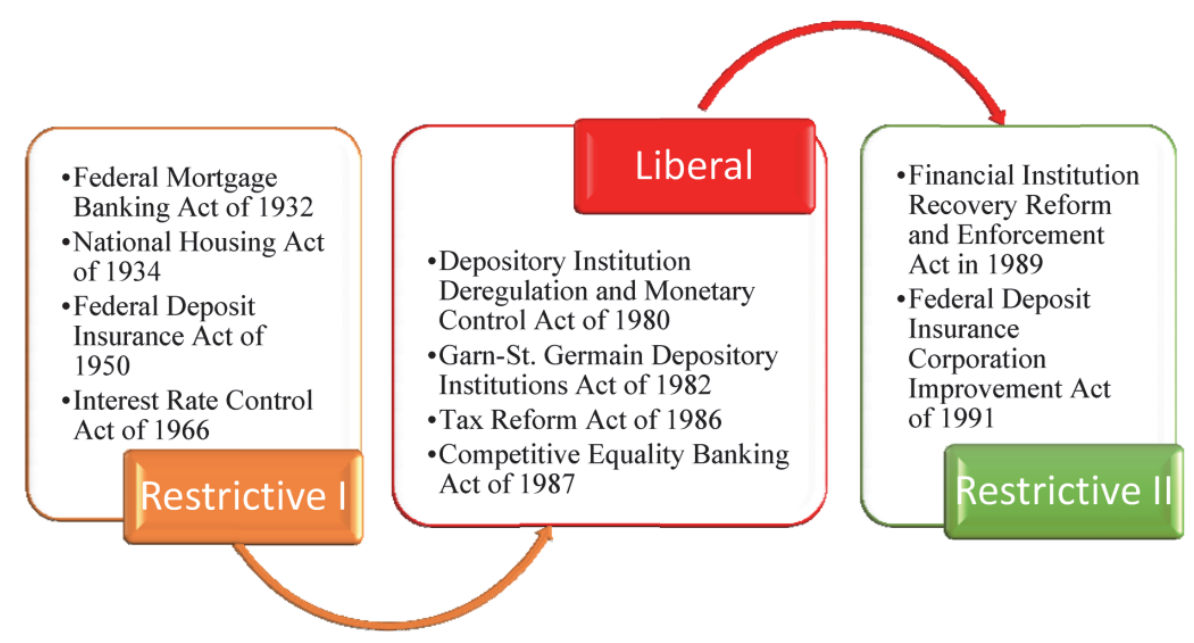

Fig. 1. Savings and Loan Market Regulation Phases

vate entities, and as the risks grew the government should not insure such risks without getting anything in return. As a result, the thrifts indulged themselves into high-risk high-return investments, and the government had to pay for the risks in the case of failure. T. Metaxas and G. Trompatzi (2015) state that the monitoring system of the Savings and Loan market of that time "imposed a loose regulatory framework and also had flimsy foundations."

The Depository Institution Deregulation and Monetary Control Act of 1980 (DIDMCA) was created with intention to gradually eliminate the limitations on the interest rates payable on deposits and accounts, to increase loans and investments up to $20 \%$ of the thrifts' assets, to allow such services as Negotiable order of Withdrawal checking accounts (NOW), trust activities, and credit cards (Jang, 2015). However, the invisible hand of the free market did not work, and by 1982 the number of problem thrifts reached 744 with 76 failures (Steinreich \& Oglesby, 2016).

The Garn-St. Germain Depository Institutions Act of 1982 has given the thrifts even more power: it eliminated deposit rate ceilings, reduced required capital levels on the balance sheets and loosened restrictions on allowable business activities for the thrifts (Kao, 2011). The Garn-St Germain gave authority to state-chartered thrifts to operate in the same way as the federally chartered ones (Jang, 2015). The elimination of the restrictions and the relaxation of the capital requirements allowed the thrifts to "operate with a high leverage ratio and generate extraordinary returns on capital" (Cassell, 2016). The deregulation did not help to improve the state of the Savings and Loan market, and the problem thrifts numbered 689 with 54 failures in 1983 and 748 with 27 failures in 1984. Tax Reform Act of 1986 reformed the taxation in the real-estate industry, adversely affecting the
Savings and Loan market, so in 1986 there were 51 failed thrifts, while in 1988 - 222 (Steinreich \& Oglesby, 2016). This data clearly shows that the free market competition did not work out. We agree with M. Mitschow and M. Schinski, who think that "establishing special rules for certain economic players creates market distortions" (2011). Instead of favorable treatment, restrictive measures were required.

The third phase of the Savings and Loan market regulation was restrictive. As it was mentioned in Section 3, FIRREA of 1989 and FDICIA of 1991 reorganised the market completely by eliminating old regulators and introducing new authorities. This time the restrictive policy worked to the benefit of the Savings and Loan market. The case of the Savings and Loan crisis demonstrates on practice the equal harm of overregulation and deregulation. State economy is a sensitive area, which should not be run by such extreme flows like free market or pure socialism. Healthy economy requires the right amount of regulation, based on the fundamental knowledge of economics.

\section{Conclusion}

The conducted analysis of the recent research publications on the Savings and Loan crisis has shown that the key roles throughout the crisis were played by the U.S. Presidents, the U.S. Congress and the various government organizations, appointed to monitor the performance of the Savings and Loan market players. The crisis was initiated by the shortfalls of overregulation and aggravated by the deregulation. The Garn-St. Germaine Depository Institutions Act is a bright example of a direct domestic governmental industryspecific regulation, relaxing the market restrictions without regard to the complexity and dynamics of the economy. We strongly believe that further study on the Savings and Loan Crisis can yield more important observations for future policy makers. 


\title{
References
}

Cassell M.K. (2016). A tale of two crises: Germany's Landesbanken and the United States' savings and loans. Journal of Banking Regulation, 17(1-2), 73-89. DOI: 10.1057/jbr.2015.11

Jang B. (2015). From the Savings and Loan Association Crisis of the 1980s to the Dodd-Frank Wall Street Reform and Consumer Protection Act: The Effect of the Dodd-Frank Act on US Thrifts and the Lesson for the Korean Savings Bank Crisis.

Kao E.S. (2011). Moral hazard during the savings and loan crisis and the financial crisis of 2008-09: implications for reform and the regulation of systemic risk through disincentive structures to manage firm size and interconnectedness. NYU Ann. Surv. Am. L., 67, 817.

Metaxas T., \& Trompatzi G. (2015). From the bank panic of 1907 to the great depression of 1929 and the savings and loan crisis of the 1980s: Comparative analysis and lessons for the future. Applied Econometrics and International Development, 15(1), 79-96.

Mitschow M., \& Schinski M. (2011). A Commentary on the Relationship between the Subprime Mortgage Crisis and the Savings and Loan Debacle. The BRC Journal of Advances in Business, 1(2), 140-157.

Steinreich D., \& Oglesby R.A. (2016). The Savings and Loan Debacle Twenty-Five Years Later: A Critical Appraisal, Interest-Group Theory Re-Examination, and Final Closing of the Book. Journal of Accounting and Finance, 16(3), 96.

Anna Konar, MScEcon, MScAgro, AScBA, CertIFR, Certified Management Accountant, Institute of Management Accountants, Doha, Qatar, annakonar@gmail.com

Received December 20, 2018

УДК 339.13.017

DOI: $10.14529 / \mathrm{em} 190110$

\section{КРЕДИТНО-СБЕРЕГАТЕЛЬНЫЙ КРИЗИС И РЕГУЛИРОВАНИЕ РЫНКА}

\section{А.Н. Конар}

\section{Институт специалистов по управленческому учету, Доха, Катар}

\begin{abstract}
Предметом данной статьи является кредитно-сберегательный кризис и влияние на него регулирования рынка. Цель данной статьи - подготовить обзор научных исследований, проведенных по данной теме, и с его помощью проанализировать её с расстояния в почти три десятилетия. В данной статье приводится анализ факторов, игравших ключевую роль от начала до окончания кредитно-сберегательного кризиса, недостатков регулирования, которые повлияли на кредитно-сберегательный рынок, и уровня регулирования Закона Гарна-Сент-Жермена о депозитных учреждениях. Проведенный анализ недавних публикаций по теме кредитносберегательного кризиса показал, что ключевые роли на протяжении всего кризиса играли президенты США, Конгресс США и различные правительственные организации, назначенные для контроля за деятельностью участников кредитно-сберегательного рынка. Кризис был инициирован по причине чрезмерного регулирования и усугублен дерегулированием.

Ключевые слова: кредитно-сберегательный кризис, регулирование рынка, дерегулирование, кредитно-сберегательные ассоциации.
\end{abstract}

Конар Анна Николаевна, магистр экономики, сертифицированный специалист по управленческому учету, Институт специалистов по управленческому учету, Доха, Катар, annakonar@gmail.com

Поступила в редакцию 20 декабря 2018 г.

\section{ОБРАЗЕЩ ЦИТИРОВАНИЯ}

Konar, A. Savings and Loan Crisis and Market Regulations / A. Konar // Вестник ЮУрГУ. Серия «Экономика и менеджмент». - 2019. - Т. 13, № 1.C. $98-101$. DOI: $10.14529 / \mathrm{em} 190110$

\section{FOR CITATION}

Konar A. Savings and Loan Crisis and Market Regulations. Bulletin of the South Ural State University. Ser. Economics and Management, 2019, vol. 13, no. 1, pp. 98-101. DOI: 10.14529/em190110 